\title{
Dunnigan-Type Familial Partial Lipodystrophy: Understanding and Treating the Syndrome
}

\author{
Ana Raisa Jatahy Santos ${ }^{1,2}$, Sabrina Pinto Ferreira', Moacir Benazzi', Mara Capra1, \\ Helen Paula Apparicio Medeiros ${ }^{1}$, Ana Luísa de Jesus ${ }^{1}$, Mirella Hansen de Almeida1,3, \\ Larissa Bianca Paiva Cunha de Sá1, Alberto Krayyem Arbex ${ }^{1,4}$ \\ ${ }^{1}$ Division of Endocrinology, IPEMED Medical School, Rio de Janeiro, Brazil \\ ${ }^{2}$ Porto Velho Garrison Hospital-HGuPV, Porto Velho, Brazil \\ ${ }^{3}$ Division of Endocrinology, Central Air Force Hospital, Rio de Janeiro, Brazil \\ ${ }^{4}$ Diabetology Department, Malteser Krankenhaus St. Franziskus-Hospital, Flensburg, Germany \\ Email: anarjatahy@gmail.com
}

How to cite this paper: Santos, A.R.J., Ferreira, S.P., Benazzi, M., Capra, M., Medeiros, H.P.A., de Jesus, A.L., de Almeida, M.H., de Sá, L.B.P.C. and Arbex, A.K. (2017) Dunnigan-Type Familial Partial Lipodystrophy: Understanding and Treating the Syndrome. Open Journal of Endocrine and Metabolic Diseases, 7, 22-34. http://dx.doi.org/10.4236/ojemd.2017.71003

Received: December 6, 2016

Accepted: January 3, 2017

Published: January 6, 2017

Copyright $\odot 2017$ by authors and Scientific Research Publishing Inc. This work is licensed under the Creative Commons Attribution International License (CC BY 4.0).

http://creativecommons.org/licenses/by/4.0/ (c) (i) Open Access

\begin{abstract}
Dunnigan-type partial lipodystrophy, which is characterized by a number of metabolic alterations, change in body fat distribution, and autosomal dominant inheritance pattern, is rare in the general population. Objective: To report the case of an adolescent with clinical and laboratory findings suggestive of Dunnigan-type partial lipodystrophy. Methods: Case report and literature review. Results: A 15-year-old adolescent presented at the clinic complaining of darkening of skin folds on her trunk and back. During physical examination, the presence of serious acanthosis nigricans in her cervical region, axillae, and intergluteal space was noted. Hirsutism in androgen-dependent areas was also observed, as well as relevant reduction of subcutaneous adipose tissue in the limbs, gluteal region, abdomen, and trunk and fat accumulation in the face and chin. Discussion. Dunnigan-type familial partial lipodystrophy is a rare dominant autosomal disease resulting from a heterozygous missense mutation in the LMNA gene, known as LPF type 2 (Dunnigan variant), which encodes the nuclear protein A/C-type lamin. It is characterized by the progressive disappearance of the subcutaneous adipose tissue in the limbs, gluteal region, abdomen, and trunk, with onset in puberty, followed by fat accumulation in other areas such as the face, chin, labia majora, and intra-abdominal region, leading to hypertrophy that may mimic the Cushing's syndrome phenotype. Affected patients display marked insulin resistance and may consequently develop diabetes mellitus, acanthosis nigricans, hirsutism, and polycystic ovary syndrome. Conclusion: This case report highlights the importance of suspecting Dunnigan-type familial partial lipodystrophy in clinical practice. Early clinical diagnosis allows for measures that minimize the severe metabolic disorders associated with this disease and, consequently, these adolescents' self-esteem issues.
\end{abstract}




\section{Keywords}

Dunnigan-Type Familial Partial Lipodystrophy, Insulin Resistance, Heterozygous Mutation

\section{Introduction}

Lipodystrophies are a heterogeneous class of adipose tissue disorders characterized by body fat loss. The acquired forms are more common. Among the familial or genetic forms, the most prevalent is type-2 familial partial lipodystrophy (Dunnigan variant; FPLD2). This disease is characterized by the loss of subcutaneous tissue in the extremities and trunk and fat accumulation on the neck [1] [2]. Patients display severe insulin resistance, with subsequent development of diabetes mellitus, acanthosis nigricans, hepatic steatosis, and polycystic ovary syndrome [3].

The prognosis of this syndrome is linked to metabolic and cardiac complications. Body dysmorphia related to this syndrome can cause serious psychological disorders in patients, such as depression and social repulsion [4]. Because no medication has been able to reverse the effects of lipodystrophy, therapy is directed toward prevention and treatment of diabetes mellitus, pancreatitis, and cardiovascular disease [5]. The treatment includes changes in lifestyle, the use of insulin sensitizers such as metformin and glitazones, and subcutaneous leptin replacement [3] [6].

\section{Case Report}

A black female patient, 15 years of age, was referred to an endocrinology clinic for hyperandrogenism. Her main complaint was "dark spots on her skin". During physical examination, the patient had weight, height, body mass index, and abdominal circumference of $58 \mathrm{~kg}, 164 \mathrm{~cm}, 21.56 \mathrm{~kg} / \mathrm{m}^{2}$, and $67 \mathrm{~cm}$, respectively. There was substantial reduction in the gluteal area, abdomen, and upper and lower limbs. In addition, coarse facies; enlargement of the hands and feet; a hirsutism score of 14 on the Ferriman-Gallwey scale; and acanthosis nigricans in the cervical region, groin, and axillae were observed. Fat accumulation was prominent in the facial, neck, and dorsal regions. Arterial pressure was 120/80 $\mathrm{mmHg}$, with normal cardiac and lung auscultation. The abdomen was flat and flaccid, with no visceromegaly. Menarche occurred at 11 years old, followed by regular menstrual cycles. The patient denied a similar phenotype in any family members.

Laboratory exams were performed to investigate hyperandrogyny and insulin resistance (Table 1$)$.

Pelvic ultrasound (10.08.16) showed uterus in AVF with homogeneous texture, measuring $8.0 \times 4.0 \times 4.2 \mathrm{~cm}$, with endometrial echo of $2.1 \mathrm{~mm}$. Right ovary $(29 \times 18 \mathrm{~mm})$ and left ovary $(24 \times 18 \mathrm{~mm})$. 
Table 1. Initial laboratory tests and clinical monitoring.

\begin{tabular}{|c|c|c|c|c|c|c|c|}
\hline Tests & Normal values & Sep. 15 & Dec. 15 & Mar. 16 & Apr. 16 & May. 16 & Jul. 16 \\
\hline Basal insulin & $\leq 29.1 \mu \mathrm{IU} / \mathrm{mL}$ & 57.50 & - & 10 & 8.3 & - & - \\
\hline HOMA IR & $>2.15$ & 186.5 & - & 1.8 & 1.43 & - & - \\
\hline 25-OH Vitamin D & $30-100 \mathrm{ng} / \mathrm{mL}$ & 20.9 & - & 44.2 & - & - & - \\
\hline Free Testosterone & $0.3-3.2 \mathrm{pg} / \mathrm{mL}$ & 1.05 & - & - & 0.60 & - & - \\
\hline Total testosterone & $<75 \mathrm{mg} / \mathrm{dL}$ & 48 & 24 & - & 22 & - & 43 \\
\hline IGF-1 & $200-900 \mu \mathrm{g} / \mathrm{L}$ & - & - & - & - & 425 & - \\
\hline HDL & $\geq 60 \mathrm{mg} / \mathrm{dL}$ & 36 & - & - & - & - & - \\
\hline Triglycerides & $<100 \mathrm{mg} / \mathrm{dL}$ & 149 & - & - & - & - & - \\
\hline SDHEA & $35-430 \mu \mathrm{g} / \mathrm{dL}$ & 113 & - & - & - & - & 160 \\
\hline $17 \beta$-estradiol & $1.3-266.0 \mathrm{pg} / \mathrm{mL}$ & - & 20 & - & - & - & - \\
\hline FSH & $3.9-10 \mathrm{mUI} / \mathrm{mL}$ & - & 4.26 & - & - & - & - \\
\hline LH & $1.7-7.2 \mathrm{mUI} / \mathrm{mL}$ & - & 3.04 & - & - & - & - \\
\hline Androstenedione & $0.3-3.7 \mathrm{pg} / \mathrm{mL}$ & - & - & - & - & - & 2.1 \\
\hline Fasting blood glucose & $70-100 \mathrm{mg} / \mathrm{dL}$ & 73 & - & - & - & - & - \\
\hline LDL & $101-130 \mathrm{mg} / \mathrm{dL}$ & 78 & - & - & - & - & - \\
\hline TGO & $\leq 30 \mathrm{U} / \mathrm{L}$ & 21 & - & - & - & - & - \\
\hline TGP & $\leq 35 \mathrm{U} / \mathrm{L}$ & 23 & - & - & - & - & - \\
\hline TSH & $0.5-4.4 \mu \mathrm{UI} / \mathrm{mL}$ & 1.24 & - & - & - & - & - \\
\hline
\end{tabular}

The suspected diagnosis was FPLD2 with severe clinical and laboratory hyperandrogyny and insulin resistance.

Metformin XR $1000 \mathrm{mg} /$ day was used as the initial treatment, which was increased to $2000 \mathrm{mg} /$ day after the first month, in association with vitamin D3 administration of 50,000 UI/week for 8 weeks. Metformin XR was increased to $2500 \mathrm{mg} /$ day after 2 months of treatment; then, pioglitazone at a dosage of 15 $\mathrm{mg} /$ day was added. For the purpose of improving clinical hyperandrogeny, in the fourth month of treatment, an oral contraceptive (ethinyl estradiol 0.035 $\mathrm{mcg}+$ cyproterone $2 \mathrm{mg}$ ) was initiated, and the dose of pioglitazone was increased to $30 \mathrm{mg} /$ day. Later, cyproterone $50 \mathrm{mg}$ was added for 10 days/month. While the patient was being monitored, she maintained her weight $(58 \mathrm{~kg})$, her skin spots cleared, cervical and axillar acanthosis improved, body hair decreased (Ferriman-Gallwey score $=10$ ), and acne improved. The patient did not undergo genetic assessment to confirm FPLD2.

\section{Classification of Lipodystrophies}

For many years, lipodystrophies have been classified according to their clinical characteristics, such as family history, age at appearance, form of progression, and pattern of subcutaneous adipose tissue loss. With advances in genetic testing, the genetic bases of these pathologies are now better understood and can 
confirm diagnosis and classification. Lipodystrophies are classified with regard to their origin (acquired or familial) or according to the extent of subcutaneous adipose tissue loss (generalized or partial) [5]. It is a phenotypic, genetically heterogeneous disease, caused by mutations in the LMNA, PPARG, AKT2, PLIN1, CAV1, and CIDEC genes [4]. The main clinical characteristics of lipodystrophies and its classifications are described in Table 2.

\section{Diagnosis of Dunnigan-Type Lipodystrophy}

FPLD2, also called Kobberling-Dunnigan syndrome or Dunnigan-type familial partial lipodystrophy, is an autosomal dominant disorder caused by missense mutations in the A/C lamin or LMNA gene [7]. Diseases related to mutations in the LMNA gene are highly heterogeneous, including neuromuscular and cardiac dystrophies, lipodystrophies, and precocious aging syndromes [8].

FPLD2 is diagnosed based on clinical and laboratory assessments and genetic studies. Clinically, there is progressive loss of subcutaneous adipose tissue in the

Table 2. Main lipodystrophy characteristics and classification.

\begin{tabular}{|c|c|c|c|c|c|}
\hline & & & $\begin{array}{l}\text { Onset age of } \\
\text { lipodystrophy }\end{array}$ & Distribution of adipose tissue & $\begin{array}{c}\text { Clinical and biological } \\
\text { parameters }\end{array}$ \\
\hline \multirow{5}{*}{ Genetic } & Generalized & $\begin{array}{l}\text { BSCL1 BSCL2 } \\
\text { BSCL3 }\end{array}$ & $\begin{array}{l}\text { Childbirth or early } \\
\text { childhood }\end{array}$ & Complete lipoatrophy & \\
\hline & \multirow{4}{*}{ Partial } & FPLD2 & Puberty & $\begin{array}{c}\text { Lipoatrophy of the limbs and } \\
\text { buttocks, increase of fat in the face } \\
\text { and neck }\end{array}$ & $\begin{array}{l}\text { Acanthosis nigricans } \\
\text { Dyslipidemia } \\
\text { Diabetes }\end{array}$ \\
\hline & & Metabolic laminopathy & Puberty & Light lipodystrophy or absent & \\
\hline & & FPLD3 & Puberty & Lower body lipoatrophy & $\begin{array}{l}\text { Hypertension } \\
\text { Acanthosis nigricans } \\
\text { Dyslipidemia } \\
\text { Diabetes }\end{array}$ \\
\hline & & AKT2-linked & & Partial lipodystrophy & $\begin{array}{c}\text { Hypertension } \\
\text { Acanthosis nigricans } \\
\text { Diabetes }\end{array}$ \\
\hline \multirow{4}{*}{ Acquired } & Generalized & Lawrence Syndrome & $\begin{array}{l}\text { Childhood or } \\
\text { adulthood }\end{array}$ & Complete lipoatrophy & $\begin{array}{l}\text { Sometimes panniculitis, } \\
\text { Acanthosis nigricans } \\
\text { Dyslipidemia } \\
\text { Diabetes }\end{array}$ \\
\hline & \multirow[t]{2}{*}{ Partial } & $\begin{array}{l}\text { Barraquer-Simmons } \\
\text { Syndrome }\end{array}$ & $\begin{array}{l}\text { Adolescence or } \\
\text { beginning of } \\
\text { adulthood }\end{array}$ & $\begin{array}{l}\text { Lipoatrophy in upper part of the } \\
\text { body } \\
\text { Lower body fat accumulation }\end{array}$ & $\begin{array}{l}\text { Infrequent metabolic } \\
\text { alterations } \\
\text { Sometimes low C3 and } \\
\text { membranoproliferative } \\
\text { glomerulonephritis }\end{array}$ \\
\hline & & Hypercortisolism-related & Usually adulthood & $\begin{array}{l}\text { Lower lipoatrophy } \\
\text { Fat accumulation in the upper part } \\
\text { of the body }\end{array}$ & $\begin{array}{c}\text { Dyslipidemia } \\
\text { Frequently with diabetes }\end{array}$ \\
\hline & $\begin{array}{c}\text { Generalized } \\
\text { or Partial }\end{array}$ & HIV-related & Usually adulthood & $\begin{array}{l}\text { Peripheral lipoatrophy } \\
\text { Central lipoatrophy or fat } \\
\text { accumulation }\end{array}$ & $\begin{array}{c}\text { Dyslipidemia } \\
\text { Sometimes diabetes }\end{array}$ \\
\hline
\end{tabular}

AR: autosomal recessive, AD: autosomal dominant, BSCL: Berardinelli-Seip congenital lipodystrophy, FPLD: familial partial lipodystrophy, HIV: human immunodeficiency virus. Source: Endocr Dev. 2010; 19: 1-20. Published online 2010 June 15. doi: 10.1159/000316893. 
limbs, trunk, and body and fat accumulation in the face and neck, which are associated with grave metabolic disorders including insulin resistance (with acanthosis nigricans in skin fold regions), glucose intolerance, diabetes mellitus, dyslipidemia, and hepatic steatosis [9]. The progressive loss of subcutaneous adipose tissue in the limbs and trunk is diagnosed via body composition analysis with dual energy X-ray densitometry, which demonstrates accentuated body fat reduction in affected patients [10].

To assess metabolic disorders, the laboratory panel must include fasting plasma glucose, HbA1c, lipid profile, insulin, transaminase, and serum leptin dose. Upper abdomen ultrasonography may help in assessing hepatic steatosis.

Genetic analyses demonstrate missense mutations in the LMNA gene [11], which are associated with defective adipogenesis, premature death of adipocytes, and lipotoxicity [12]. The first report of a mutation in the LMNA gene, located on chromosome 1q21-22, related to FPLD2, in 2000, confirmed the mutation as p.R482Q [11].

\section{Dunnigan-Type Lipodystrophy Phenotype Assessment}

FPLD2 presents during or soon after puberty. Lipoatrophy in the limbs, gluteal region, abdomen, and trunk is followed by fat accumulation in the face, chin, neck, back, intra-abdominal region, and labia majora and apparent muscle hypertrophy, typically more rapidly identified in female patients [8] [13]. Some women display hyperandrogyny, clinically manifested by severe hirsutism and alterations in the menstrual cycle such as oligomenorrhea. Proximal enlargement of the fingers (producing an appearance of fused fingers) and acanthosis nigricans are also more frequently observed among females [14].

Furthermore, affected women are particularly predisposed to insulin resistance and complications, which include glucose intolerance, diabetes mellitus, hypertriglyceridemia, reduction of high-density lipoprotein cholesterol, increase of arterial pressure, elevation of uric acid, hepatic steatosis, and precocious arteriosclerosis, with an increase in the risk of cardiovascular disease and predisposition to polycystic ovary syndrome [13] [15] [16]. In fact, it has been suggested that lipodystrophies are etiologically linked to polycystic ovary syndrome [17] and, in isolated publications, to some obstetric complications [18]. In milder forms of the disease, the phenotype may be indistinguishable from the regular metabolic syndrome. Diabetes mellitus may be the first sign of lipodystrophy [19].

Despite being a rare disease, better understanding of this pathology may reveal insights into the mechanisms underlying insulin resistance and its metabolic consequences. Patients with FPLD2 and insulin resistance are usually glucose intolerant or have diabetes mellitus, dyslipidemia, hepatic steatosis, acanthosis nigricans, and elevated risk of cardiovascular disease. This risk is similar to that described for visceral obesity, which is associated to the development of metabolic syndrome and increase of cardiovascular morbidity and mortality [15] [20]. 
The gain in muscle mass could further be related to insulin resistance and the side effects of hyperinsulinemia in IGF-I receptors [21]. Both hyperandrogyny and hyperinsulinemia may play a role in muscle gain in women with polycystic ovary syndrome [22]. Muscular hypertrophy could also be explained by the accumulation of lipids within myocytes. This phenomenon has been demonstrated in insulin resistance, which has been related to intramyocellular triglyceride levels, and failure to store subcutaneous fat in the extremities and trunk and may cause aberrant fat deposition in the muscle [23].

\section{Genetic Assessment of Lipodystrophies}

Familial partial lipodystrophy (FPL) has an autosomal dominant inheritance pattern. The main familial forms are FPLD2 and Berardinelli-Seip syndrome.

FPLD2 is associated with mutations in the LMNA gene [24], located on chromosome lq21-22, which lead to defective adipogenesis [25]. The genesis of FPLD2 is closely related to alterations in the structure and function of the nuclear envelope of eukaryotic cells, which are composed of three parts: the nuclear membrane, the nuclear pore complexes (NPCs), and the nuclear lamina [20]. The nuclear lamina is spotted by the NPCs, which regulate the passage of macromolecules between the nucleus and the cytoplasm [26]. The nuclear lamina, organized as an intertwined mesh of fibers inside the nuclear membrane, interacts with the NPCs and nuclear envelope transmembrane proteins (NETs), promoting organization and NPC interconnection, and NET anchoring to the nuclear membrane. Consequently, the nuclear lamina performs numerous biological functions, including maintenance of nuclear structural integrity, chromatin organization, control of cell division during mitosis and meiosis, and regulation of the access of transcription factors to the nucleus [27].

The LMNA gene contains 12 exons and encodes $\mathrm{A}$ and $\mathrm{C}$ lamins through alternative exon 10 processing. Lamins A and C polymerize with B-type lamins, forming the nuclear lamina, a meshwork of intermediate-type filaments located between chromatin and the internal nuclear membrane, with functions ranging from maintenance, nuclear structure, spatial arrangement of the nuclear pores, transcriptional regulation and organization of chromatin [24].

Diseases related to mutations in the LMNA gene are highly heterogeneous, including neuromuscular and cardiac dystrophies, lipodystrophies, and precocious aging syndromes [15].

\section{Differential Diagnosis}

For the differential diagnosis of Dunnigan-type familial partial lipodystrophy, Berardinelli-Seip syndrome [28] must be taken into account. Both genetic syndromes are characterized by severe insulin resistance and hyperinsulinemia, associated with lipoatrophy, lipodystrophy, and hypertriglyceridemia. Dunnigan syndrome manifests as fat accumulation in the face, autosomal dominant inheritance pattern, and hyperinsulinemia, which is associated with lipoatrophy, lipodystrophy, and hypertriglyceridemia, and it is caused by mutations in the 
LMNA gene. Berardinelli syndrome, another form of generalized congenital lipoatrophy, is caused by a mutation in the BSCL2 or AGPAT2 gene and demonstrates autosomal recessive transmission. The most common clinical manifestations of Berardinelli syndrome are acanthosis nigricans, steatosis with hepatomegaly, and tall stature. Acromegaloid features, cardiomyopathy, hypertension, and developmental disability may also occur. Among women, other findings include clitoromegaly, hirsutism, polycystic ovaries, and reduced fertility.

Cushing's syndrome, characterized by endogenous or exogenous hypercortisolism, is another important differential diagnosis of FPLD2 [29]. The main symptoms associated with the excess of glucocorticoids are weight gain, lethargy, weakness, menstrual irregularity, loss of libido, hirsutism, acne, purple cutaneous stretch marks, hyperpigmentation, depression, and psychosis.

Other differential diagnoses of FPLD2 include polycystic ovary syndrome [30], which may also involve oligomenorrhea or amenorrhea. In addition, hyperandrogyny, particularly in the form of hirsutism, acne, androgenetic alopecia, and obesity may occur. Insulin resistance and acanthosis nigricans are also frequent.

\section{Treatment of Dunnigan Lipodystrophy}

FPLD2 treatment must be based on an interdisciplinary approach that includes an endocrinologist, nutritionist, and psychologist. Considering the metabolic and aesthetic complications caused by FPLD2, the therapeutic approach should be individualized to improve the patient's quality of life. In addition to pharmacological therapy, lifestyle change counseling should emphasize a balanced diet with low fat and sugar intake and regular physical activity, preferably aerobic, as essential to improving these patients' metabolic profile.

The use of sensitizers to improve insulin resistance, such as metformin and glitazones, is of paramount importance. Additionally, lipid-lowering drugs and even recombinant leptin are warranted in specific cases [31]. The recommended doses for metformin and pioglitazone are $2.250 \mathrm{mg} /$ day and $30 \mathrm{mg} / \mathrm{day}$, respectively [32]. If glycaemia is not controlled with oral medication and lifestyle change counseling, insulin use may be necessary.

Lipid-lowering therapy with fibrates should be initiated to control high triglyceride levels [33]. Some authors recommend supplementation with omega-3 fatty acids to help reduce triglyceride levels [31]. Combination therapy with statins may be administered, but they are contraindicated in patients receiving gemfibrozil due to a high risk of myopathy. Table 3 summarizes the main drug classes used as lipid-lowering agents.

Oral estrogen therapy should be avoided in female patients with FPLD2 and associated polycystic ovary syndrome due to a risk of increasing triglyceride levels [33]. The use of recombinant leptin (metreleptin) for the treatment of genetic lipodystrophic syndromes has been proposed recently, with the aim to improve glycemic and lipid control, hepatic steatosis, insulin resistance, and hyperpulsatility of pituitary gonadotropins associated with polycystic ovary syndrome 
Table 3. Oral lipid-lowering agents used in FPLD2 treatment.

\begin{tabular}{llc}
\hline Agent & & Dose $\mathrm{mg} / \mathrm{day}$ \\
\hline & Bezafibrate & 400 to 600 \\
& Ciprofibrate & 100 \\
& Etofibrate & 500 \\
& Fenofibrate & 250 \\
& Simvastatin & 20 to 40 \\
& Lovastatin & 10 to 80 \\
& Pravastatin & 20 to 40 \\
& Fluvastatin & 20 to 80 \\
& Atorvastatin & 10 to 80 \\
& Rosuvastatin & 10 to 40 \\
\hline
\end{tabular}

[34]. The suggested recombinant leptin dose is based on the patient's body weight (Table 4).

Aesthetic treatments for FPLD2 include facial filling, autologous adipose tissue transplant, and reconstructive surgeries such as liposuction, with the possibility of recurrence of abnormal adipose tissue deposition in areas where liposuction is performed [35] [36]. Dermatological treatment is suggested for skin bleaching caused by acanthosis, along with hair removal using definitive depilation.

\section{Discussion}

FPLD2 is a rare disease of autosomal dominant inheritance, resulting from a heterozygous missense mutation in the LMNA gene [13]. FPLD2 usually has an earlier onset and is more and easily recognizable in women because of the muscle hypertrophy phenotype and significant subcutaneous adipose tissue disorder in the extremities, with variable reduction in the trunk [37]. Here we report the case of an adolescent with a clinical history and classic FPLD2 phenotype. She was investigated at 15 years of age, upon demonstrating significant metabolic alterations in her initial laboratory exams. On physical examination, and abnormal pattern of fat distribution and severe lipodystrophy were noted, followed by signs of insulin resistance (severe acanthosis nigricans), coarse facies, enlargement of the hands and feet, and clinical hyperandrogyny, characterized by acne and hirsutism.

The progressive accumulation of prelamin resulting from the mutation of the R482W gene reduces the interaction of SREBP1c with DNA, hindering transcription of PPAR $\gamma$. This mechanism also hinders transcription of the genes involved in controlling the production, transport, and use of glucose, as well as differentiation between preadipocytes and adipocytes [37]. This effect assumes particular importance in the subcutaneous cellular tissue of limbs and trunk, due to the marked reduction of adipogenesis in these sites. Consequently, lipid deposition increases in other sites, including the intra-abdominal cavity [38] [39]. 
Table 4. Recombinant leptin doses.

\begin{tabular}{cc}
\hline Weight & Dose $\mathrm{mg} / \mathrm{Kg} /$ day \\
\hline Up to $40 \mathrm{Kg}$, both sexes & 0.06 to 0.13 \\
Over $49 \mathrm{Kg}$, men & 2.5 to 10 \\
Over $40 \mathrm{Kg}$, women & 5 to 10 \\
\hline
\end{tabular}

Thus, the interaction between lamin A precursors such as SEBP1c reduces expression of PPAR $\gamma$. Moreover, it may represent an important pathological mechanism underlying lipodystrophies, which justifies the use of glitazones (a selective ligand of PPAR $\gamma$ ) for the treatment of these disorders. PPAR $\gamma$ activation by glitazones reenables the differentiation of preadipocytes in subcutaneous adipose cellular tissue [40], reducing visceral fat deposition [38]. Furthermore, the transcription of insulin-responsive genes and the capacity of adipose tissue to remove fatty acids from circulation are increased, thus reducing intrahepatic and intramuscular deposits and preventing insulin resistance, which is induced by fatty acids [41].

Treating FPLD2 patients with glitazones aims to reduce serum insulin levels, clinical and laboratory indicators of hyperandrogyny, and regulate menstrual cycles in cases involving polycystic ovary syndrome [42]. The main antihyperglycemic effect of metformin involves the reduction of hepatic gluconeogenesis [43] [44]. Furthermore, it decreases the gastrointestinal absorption of glucose, despite increasing sensitivity to insulin in muscle and adipose tissues, and decreases free fatty acid levels [45]. In peripheral tissues, metformin facilitates glucose transport by increasing tyrosine kinase activity in insulin receptors [46] and translocation of glucose transporters to the cellular membrane [47] [48]. Metformin reduces insulin resistance and secretion, followed by a decrease in the production of ovarian androgens. The direct action of metformin on ovarian theca cells also reduces androgen production [49].

\section{Conclusion}

The early diagnosis of FPLD2 enables the adoption of measures that minimize severe metabolic and hyperandrogenic disorders related to this condition. A multidisciplinary approach to this disease should aim to improve patients' metabolism, quality of life, and, ultimately, self-esteem.

\section{References}

[1] Garg, A. (2011) Lipodistrofias: Distúrbios gordura corporal genéticas e adquiridas. The Journal of Clinical Endocrinology \& Metabolism, 96, 3313-3325. https://doi.org/10.1210/jc.2011-1159

[2] Bhayana, S. and Hegele, R.A. (2002) Síndromes genéticas da lipodistrofia humana. Canadian Journal of Diabetes, 26, 363-368.

[3] Agarwal, A. and Garg, A. (2006) Genetic Basis of Lipodystrophies and Management of Metabolic Complications. Annual Review of Medicine, 57, 297-311. https://doi.org/10.1146/annurev.med.57.022605.114424 
[4] Mory, P.B. (2012) Heterogeneidade fenotipica em pacientes com lipodistrofia associada a mutacoes no gene. LMNA Universidade Federal de São Paulo (UNIFESP).

[5] Jackson, S.N., Howlett, T.A., McNally, P.G., O’Rahilly, S. and Trembath, R.C. (1997) Dunnigan-Kobberling Syndrome: An Autosomal Dominant Form of Partial Lipodystrophy. QJM, 90, 27-36. https://doi.org/10.1093/qjmed/90.1.27

[6] Park, J.Y., Javor, E.D., Cochran, E.K., DePaoli, A.M. and Gorden, P. (2007) LongTerm Efficacy of Leptin Replacement in Patients with Dunnigan-Type Familial Partial Lipodystrophy. Metabolism, 56, 508-516.

https://doi.org/10.1016/j.metabol.2006.11.010

[7] Oral, E.A. and Chan, J.L. (2010) Rationale for Leptin-Replacement Therapy for Severe Lipodystrophy. Endocrine Practice, 16, 324-333.

https://doi.org/10.4158/EP09155.RA

[8] Caldas, D., da Silva Jr., W.S., Simonetti, J.P., Costa, E.V. and Farias, M.L.F. (2013) Avaliação bioquímica, hormonal e genética das famílias de duas pacientes brasileiras portadoras de lipodistrofia parcial familiar tipo 2. Arquivos brasileiros de endocrinologia e metabologia, 57, 583-593.

[9] Vilar, L., et al. (2006) Endocrinologia Clínica. 5th Edition, Guanabara Koogan, Rio de janeiro, edição 5, 624 .

[10] Guillín-Amarelle, C., Sánchez-Iglesias, S., Castro-Pais, A., Rodriguez-Cañete, L., Ordóñez-Mayán, L., Pazos, M., et al. (2016) Type 1 Familial Partial Lipodystrophy: Understanding the Köbberling Syndrome. Endocrine, 54, 411-421.

https://doi.org/10.1007/s12020-016-1002-x

[11] Krawiec, P., Mełges, B., Pac-Kożuchowska E., Mroczkowska-Juchkiewicz, A. and Czerska, K. (2016) Fitting the Pieces of the Puzzle Together: A Case Report of the Dunnigan-Type of Familial Partial Lipodystrophy in the Adolescent Girl. BMC Pediatrics, 16, 38. https://doi.org/10.1186/s12887-016-0581-2

[12] Valerio, C.M., Zajdenverg, L., de Oliveira, J.E., Mory, P.B., Moyses, R.S. and Godoy-Matos, A.F. (2012) Body Composition Study by Dual-Energy X-Ray Absorptiometry in Familial Partial Lipodystrophy: Finding New Tools for an Objective Evaluation. Diabetology \& Metabolic Syndrome, 4, 40.

https://doi.org/10.1186/1758-5996-4-40

[13] Garg, A., Peshock, R.M. and Fleckenstein, J.L. (1999) Adipose Tissue Distribution Pattern in Patients with Familial Partial Lipodistrophy (Dunnigan Variety). The Journal of Clinical Endocrinology \& Metabolism, 84, 170-174.

[14] Garg, A. (2000) Gender Differences in the Prevalence of Metabolic Complications in Familial Partial Lipodystrophy (Dunnigan Variety). The Journal of Clinical Endocrinology \& Metabolism, 85, 1776-1782.

[15] Vantyghem, M.C., Pigny, P., Maurage, C.A., Rouaix-Emery, N., Stojkovic, T., Cuisset, J.M., et al. (2004) Patients with Familial Partial Lipodystrophy of the Dunnigan Type Due to a LMNA R482W Mutation Show Muscular and Cardiac Abnormalities. The Journal of Clinical Endocrinology \& Metabolism, 89, 5337-5346. https://doi.org/10.1210/jc.2003-031658

[16] Schmidt, H.H., Genschel, J., Baier, P., Schmidt, M., Ockenga, J., Tietge, U.J., et al. (2001) Dyslipemia in Familial Partial Lipodystrophy Caused by an R482W Mutation in the LMNA Gene. The Journal of Clinical Endocrinology \& Metabolism, 86, 2289-2295. https://doi.org/10.1210/jcem.86.5.7500

[17] Decaudain, A., Vantyghem, M.C., Guerci, B., Hécart, A.C., Auclair, M., Reznik, Y., et al. (2007) New Metabolic Phenotypes in Laminopathies: LMNA Mutations in Patients with Severe Metabolic Syndrome. The Journal of Clinical Endocrinology \& Metabolism, 92, 4835-4844. https://doi.org/10.1210/jc.2007-0654 
[18] Young, J., Morbois-Trabut, L., Couzinet, B., Lascols, O., Dion, E., Béréziat, V., et al. (2005) Type A Insulin Resistance Syndrome Revealing a Novel Lamin A Mutation. Diabetes, 54, 1873-1878. https://doi.org/10.2337/diabetes.54.6.1873

[19] Panchal, R., Bosio, P. and Waugh, J. (2005) Familial Partial Lipodystrophy Complicated by Pre-Eclampsia. Journal of Obstetrics and Gynaecology, 25, 196-197. https://doi.org/10.1080/01443610500051700

[20] Donadille, B., Lascols, O., Capeau, J. and Vigouroux, C. (2005) Etiological Investigations in Apparent Type 2 Diabetes: When to Search for Lamin A/C Mutations? Diabetes \& Metabolism, 31, 527-532. https://doi.org/10.1016/S1262-3636(07)70227-6

[21] Goldberg, M. (2004) Import and Export at the Nuclear Envelope. Symposia of the Society for Experimental Biology, 1, 115-133.

[22] Garg, A., Stray-Gundersen, J., Parsons, D. and Bertocci, L.A. (2000) Morfologia do músculo esquelético e resposta ao exercício em congênita generalizada lipodistrofia. Diabetes Care, 23, 1545-1550. https://doi.org/10.2337/diacare.23.10.1545

[23] Favreau, C., Higuet, D., Courvalin, J.C. and Buendía, B. (2004) Expressão de uma lamina A mutante que causa Emery-Dreifuss, distrofia muscular inibe a diferenciação in vitro em mioblastos C2C12 de Biol. Molecular Cell, 24, 1481-1492. https://doi.org/10.1128/MCB.24.4.1481-1492.2004

[24] Garg, A. (2004) Acquired and Inherited Lipodystrophies. The New England Journal of Medicine, 350, 1220-1234. https://doi.org/10.1056/NEJMra025261

[25] Vilar, L., et al. (2013) Endocrinologia Clínica. Quinta edição, Guanabara Koogan, Rio de Janeiro, edição 5, 617-632.

[26] Herrmann, H., Bar, H., Kreplak, L., Strelkov, S.V. and Aebi, U. (2007) Intermediate Filaments: From Cell Architecture to Nanomechanics. Nature Reviews Molecular Cell Biology, 8, 562-573. https://doi.org/10.1038/nrm2197

[27] Worman, H.J. and Bonne, G. (2007) "Laminopatias": Um largo espectro de doenças humanas. Experimental Cell Research, 313, 2121-2133. https://doi.org/10.1016/j.yexcr.2007.03.028

[28] Vilar, L., et al. (2013) Endocrinologia Clínica. Quinta edição, Guanabara Koogan, Rio de Janeiro, edição 5, 436-461.

[29] Musso, C., Cochran, E., Javor, E., Young, J., Depaoli, A.M. and Gorden, P. (2005) The Long-Term Effect of Recombinant Methionyl Human Leptin Therapy on Hyperandrogenism and Menstrual Function in Female and Pituitary Function in Male and Female Hypoleptinemic Lipodystrophic Patients. Metabolism, 54, 255 263. https://doi.org/10.1016/j.metabol.2004.08.021

[30] Knochenhauer, E.S., Key, T.J., Kahsar-Miller, M., Waggoner, W., Boots, L.R. and Azziz, R. (1998) Prevalence of the Polycystic Ovary Syndrome in Unselected Black and White Women of the Southeastern United States: A Prospective Study. The Journal of Clinical Endocrinology \& Metabolism, 83, 3078-3082.

[31] SOP e Risco Cardiovascular (2006) Silva, Pardini \& Kater. Arq Bras Endocrinol Metab, 50, 281-287.

[32] Caldas, D., da Silva Júnior, W.S., Simonetti, J.P., da Costa, E.V. and de Farias, M.L.F. (2015) Biochemical, Hormonal and Genetic Evaluation of the Families of Two Brazilian Patients with Type 2 Familial Partial Lipodystrophy. Arq Bras Endocrinol Metab, 57, 583-593.

[33] Walsh, B.W., Schiff, I., Rosner, B., Greenberg, L., Ravnikar, V. and Sacks, F.M. (1991) Effects of Postmenopausal Estrogen Replacement on the Concentrations and Metabolism of Plasma Lipoproteins. The New England Journal of Medicine, 325, 1196-1204. https://doi.org/10.1056/NEJM199110243251702 
[34] Araujo-Vilar, D., Sanchez-Iglesias, S., Guillin-Amarelle, C. et al. (2015) Recombinant Human Leptin Treatment in Genetic Lipodystrophic Syndromes: The LongTerm Spanish Experience. Endocrine, 49, 139-147. https://doi.org/10.1007/s12020-014-0450-4

[35] Patni, N. and Garg, A. (2015) Congenital Generalized Lipodystrophies-New Insights into Metabolic Dysfunction. Nature Reviews Endocrinology, 11, 522-534.

[36] Anuurad, E., Bremer, A. and Berglund, L. (2010) HIV Protease Inhibitors and Obesity. Current Opinion in Endocrinology, Diabetes and Obesity, 17, 478-485. https://doi.org/10.1097/MED.0b013e32833dde87

[37] Tontonoz, P., Hu, E., Devine, J., Beale, E.G. and Spiegelman, B.M. (1995) PPAR Gamma 2 Regulates Adipose Expression of the Phosphoenolpyruvate Carboxykinase Gene. Molecular and Cellular Biology, 15, 351-357.

[38] Sewter, C.P., Blows, F., Vidal-Puig, A. and O'Rahilly, S. (2002) Regional Differences in the Response of Human Pre-Adipocytes to PPAR Gamma and RXR Alpha Agonists. Diabetes, 51, 718-723. https://doi.org/10.2337/diabetes.51.3.718

[39] Larsen, T.M., Toubro, S. and Astrup, A. (2003) PPAR Gamma Agonists in the Treatment of Type II Diabetes: Is Increased Fatness Commensurate with Long-Term Efficacy. International Journal of Obesity, 27, 147-161. https://doi.org/10.1038/sj.ijo.802223

[40] Capanni, C., Mattioli, E., Columbaro, M., Lacarelli, E., Parnaik, V.K., Novelli, G., et al. (2005) Altered Pre Lamin A Processing Is a Common Mechanism Leading to Lipodystrophy. Human Molecular Genetics, 14, 1489-1502.

https://doi.org/10.1093/hmg/ddi158

[41] Ye, J.M., Dzamko, N., Cleasby, M.E., Hegarty, B.D., Furler, S.M., Cooney, G.J., et al. (2004) Direct Demonstration of Lipid Sequestration as a Mechanism by Which Rosiglitazone Prevents Fatty-Acid Induced Insulin Resistance in the Rat: Comparison with Metformin. Diabetologia, 47, 1306-1313. https://doi.org/10.1007/s00125-004-1436-1

[42] Lüdtke, A., Heck, K., Genschel, J., Mehnert, H., Spuler, S., Worman, H.J., et al. (2005) Long-Term Treatment Experience in a Subject with Dunnigan-Type Familial Partial Lipodystrophy: Efficacy of Rosiglitazone. Diabetic Medicine, 22, 1611-1613. https://doi.org/10.1111/j.1464-5491.2005.01757.x

[43] Hundal, R.S., Krssak, M., Dufour, S., Laurent, D., Lebon, V., Chandramouli, V., et al. (2000) Mechanism by Which Metformin Reduces Glucose Production in Type 2 Diabetes. Diabetes, 49, 2063-2069. https://doi.org/10.2337/diabetes.49.12.2063

[44] Bosi, E. (2009) Metformin-The Gold Standard in Type 2 Diabetes: What Does the Evidence Tell Us? Diabetes, Obesity and Metabolism, 11, 3-8.

https://doi.org/10.1111/j.1463-1326.2008.01031.x

[45] Kirpichnikov, D., McFarlane, S.I. and Sowers, J.R. (2002) Metformin: An Update. Annals of Internal Medicine, 137, 25-33. https://doi.org/10.7326/0003-4819-137-1-200207020-00009

[46] Dominguez, L.J., Davidoff, A.J., Srinivas, P.R., Standley, P.R., Walsh, M.F. and Sowers, J.R. (1996) Effects of Metformin on Tyrosine Kinase Activity, Glucose Transport, and Intracellular Calcium in Rat Vascular Smooth Muscle. Endocrinology, 137, 113-121.

[47] Matthaei, S., Hamann, A., Klein, H.H., Benecke, H., Kreymann, G., Flier, J.S., et al. (1991) Association of Metformin's Effect to Increase Insulin-Stimulated Glucose Transport with Potentiation of Insulin-Induced Translocation of Glucose Transporters from Intracellular Pool to Plasma Membrane in Rat Adipocytes. Diabetes, 40, 850-857. https://doi.org/10.2337/diab.40.7.850 
[48] Hundal, H.S., Ramlal, T., Reyes, R., Leiter, L.A. and Klip, A. (1992) Cellular Mechanism of Metformin Action Involves Glucose Transporter Translocation from an Intracellular Pool to the Plasma Membrane in L6 Muscle Cells. Endocrinology, 131, 1165-1173.

[49] Homburg, R. (2008) Polycystic Ovary Syndrome. Best Practice \& Research Clinical Obstetrics \& Gynaecology, 22, 261-274.

https://doi.org/10.1016/j.bpobgyn.2007.07.009

Submit or recommend next manuscript to SCIRP and we will provide best service for you:

Accepting pre-submission inquiries through Email, Facebook, LinkedIn, Twitter, etc. A wide selection of journals (inclusive of 9 subjects, more than 200 journals) Providing 24-hour high-quality service User-friendly online submission system Fair and swift peer-review system Efficient typesetting and proofreading procedure Display of the result of downloads and visits, as well as the number of cited articles Maximum dissemination of your research work

Submit your manuscript at: http://papersubmission.scirp.org/ Or contact ojemd@scirp.org 